DP-883

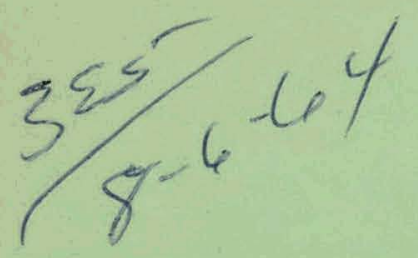

AEC RESEARCH AND DEVELOPMENT REPORT

\title{
DETERMINATION OF URANIUM ISOTOPES \\ IN IRRADIATED THORIUM
}

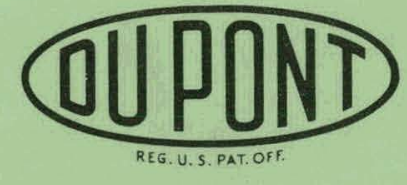

Savannah River Laboratory

Aiken, South Carolina 


\section{DISCLAIMER}

This report was prepared as an account of work sponsored by an agency of the United States Government. Neither the United States Government nor any agency Thereof, nor any of their employees, makes any warranty, express or implied, or assumes any legal liability or responsibility for the accuracy, completeness, or usefulness of any information, apparatus, product, or process disclosed, or represents that its use would not infringe privately owned rights. Reference herein to any specific commercial product, process, or service by trade name, trademark, manufacturer, or otherwise does not necessarily constitute or imply its endorsement, recommendation, or favoring by the United States Government or any agency thereof. The views and opinions of authors expressed herein do not necessarily state or reflect those of the United States Government or any agency thereof. 


\section{DISCLAIMER}

Portions of this document may be illegible in electronic image products. Images are produced from the best available original document. 
Th1s report was prepared as an account of Government sponsored work. Ne1ther the United States, nor the Commission, nor any person acting on behalf of the Commission:

A. Makes any warranty or representation, expressed or 1 mplied, with respect to the accuracy, completeness, or usefulness of the information contained in this report, or that the use of any information, apparatus, method, or process disclosed in this report may not infringe privately owned rights; or

B. Assumes any liablilties with respect to the use of, or for damages resulting from the use of any information, apparatius, method, or process disclosed in this report.

As used in the above, "person acting on behalf of the Commission" Includes any employee or contractor of the Commission, or employee of such contractor, to the extent that such employee or contractor of the Commission, or employee of such contractor prepares, disseminates, or provides access to, any information pursuant to his employment or contract with the Commission, or his employment with such contractor.

Printed in USA. Price $\$ 0.50$

Ava1lable from the Office of Technical Services

U. S. Department of Commerce Washington $25, \mathrm{D}$. C. 
Chemical Separations Processes

for Plutonium and Uranium

(TID-4500, 30th Ed.)

\section{DETERMINATION OF URANIUM ISOTOPES}

IN IRRADIATED THORIUM

\section{by}

Robert S. Ondrejcin

\section{Approved by}

H. M. Kelley, Research Manager

Analytical Chemistry Division

June 1964

E. I. DU PONT DE NEMOURS \& COMPANY

EXPLOSIVES DEPARTMENT - ATOMIC ENERGY DIVISION

TECHNICAL DIVISION - SAVANNAH RIVER LABORATORY

AIKEN, SOUTH CAROLINA

LUNIKALI AI (U/-L). I WIIH THE

UNITED STATES ATOMIC ENERGY COMMISSION 


\section{ABSTRACT}

Uranium isotopes in irradiated thorlum were determined by alpha pulse helght analysis coupled with mass analyo13. $\mathrm{Pa}^{233}$ ( $\mathrm{U}^{233}$ parent) was determined by gamma spectrometry. The precision of a single determination.of $U^{232}$ in $U^{233}$ product. was $\pm 5 \%$ at the $95 \%$ confidence limt.t. The analysis. of $\mathrm{U}^{232}$ in $\mathrm{U}^{233}$ product was confirmed by a method that combined low geometry alpha.counting; mass analysis; and coulometry. 


\section{CONTENTS}

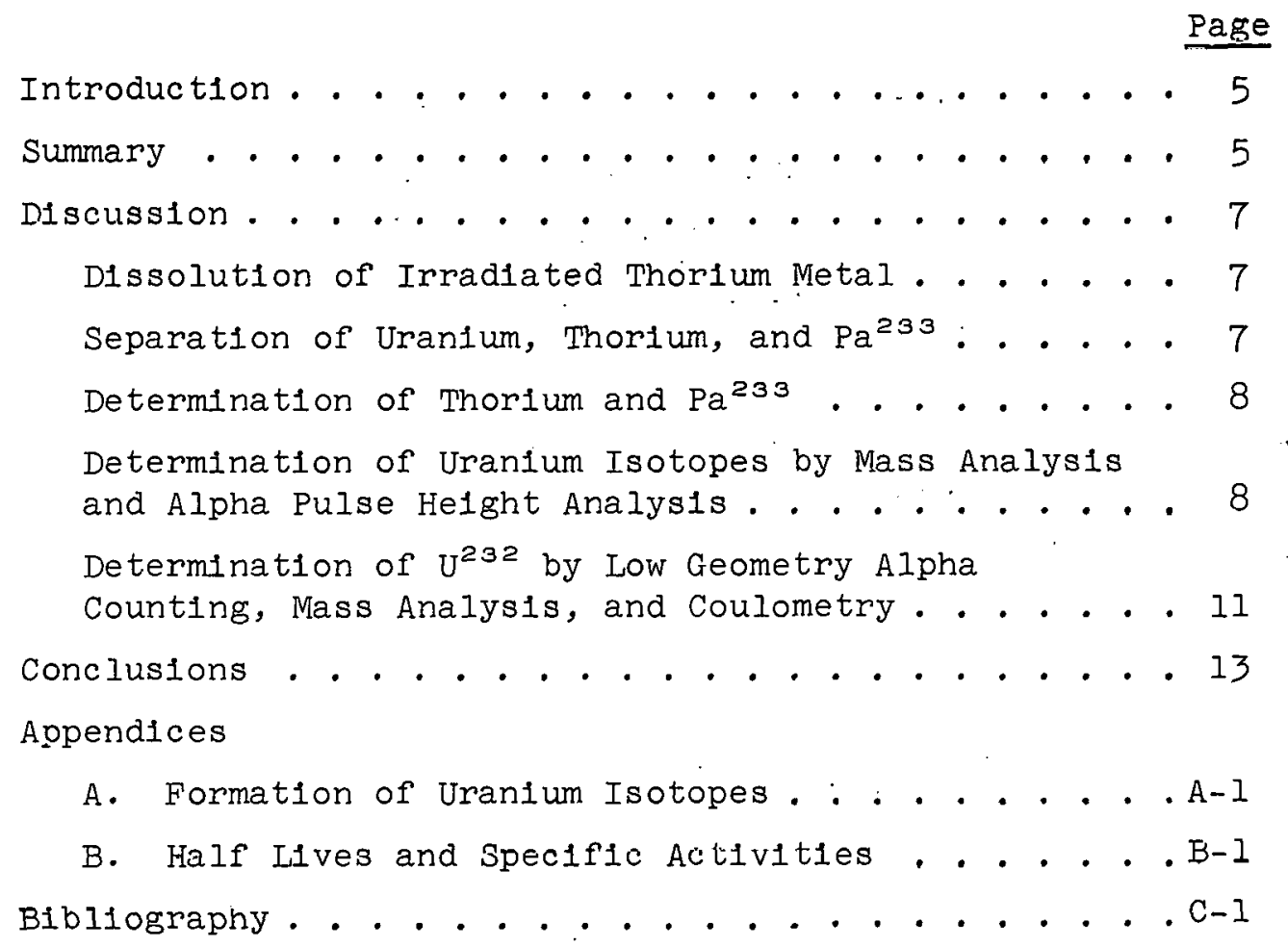




\section{LIST OF TABLES AND FIGURES}

$\underline{T a b l e}$

Page

I Recoveries from Synthetic Solution . . . . . . : 8

II Uranium Máa Analyaea . . . . . . . . . . . . . . 9

III Alpha Pulse Helght Analyses of $U^{232}$ In $U^{233}$ Product il

IV $\mathrm{U}^{232}$ in $\mathrm{U}^{233}$ Product by Coulometric-LGAC Method • . 12

Figure

1 Ion Exchange Column . . . . . . . . . . . 7

2 Alpha Pulse Height Analyses of Uranium Isotopes. . 10

$3 \mathrm{U}^{232}$ in $\mathrm{U}^{233}$ Product vs. Produced $\mathrm{U}^{233} . \cdot . .$. . II 


\section{DETERMINATION OF URANIUM ISOTOPES \\ IN IRRADIATED THORIUM}

\section{INTRODUCTION}

Uranium-233, a nuclide of interest in the breeder reactor program, can be produced by irradiating $\mathrm{Th}^{232}$ with thermal neutrons. $(1,2)$ The irradiation of thortum also produces $\mathrm{U}^{232}$ and $\mathrm{U}^{234}$, which are undesirable because:

- One product in the $U^{232}$ decay chain is thallium-208, which is a very energetic gamma emitter and increases the amount of shielding required for the $U^{233}$ product. $(3,4)$ (See Appendix A.)

- Uranium-234 dilutes the $U^{200}$ product and prevents the determination of $\mathrm{U}^{233}$ by alpha pulse height analysis (APHA) because the alpha energies are in the same range:

$$
\begin{array}{ll}
U^{233} & 4.72-4.82 \mathrm{Mev} \\
U^{234} & 4.72-4.77 \mathrm{Mev}
\end{array}
$$

Two experimental assemblies that contained target slugs of thorium were irradiated at the Savannah River Plant. The amount of uranium product per unit weight of thorlum and the $\mathrm{U}^{232}$ concentration in the $\mathrm{U}^{233}$ product were needed for planning irradiations for the production of $120 \mathrm{~kg}$ of $\mathrm{U}^{233}$. To obtain these concentrations, quantitative determinations were needed for total thorium, total $\mathrm{Pa}^{23.3}$ (parent of $\mathrm{U}^{233}$ ), total uranium, and the isotopic content of the uranium.

\section{SUMMARY}

The quantity and isotopic content of uranium produced by thermal neutron irradiation of thorium was determined by alpha counting, mass spectrometry, and APHA. An anion exchange technique was adapted for initial separation of thorium, protactinium, and uranium. Thorium was determined by colorimetry and protactinium by gamma spectrometry. The precision of a single determination of $U^{232}$ in $U^{233}$ product was $\pm 5 \%$ at the 95\% confidence limit. The $U^{232}$ content of the $U^{233}$ product was confirmed by an independent method that employed low geometry alpha counting, mass analysis, and coulometry. 
THIS PAGE

\section{WAS INTENTIONALLY LEFT BLANK}




\section{DISCUSSION}

\section{DISSOLUTION OF IRRADIATED THORIUM METAL}

Irradiated thorlum metal dissolves efficiently in 15M

$\mathrm{HNO}_{3}-0.05 \mathrm{M} \mathrm{HF}$. Massive thorium metal 1s attacked slowly by concentrated phosphoric or perchloric ac1d and dilute nitric, sulfuric, or hydrofluoric acid. Concentrated nitric acid renders the metal passive, and hydrochloric acid leaves a black residue of unknown composition that is believed to be Tho or $\mathrm{ThH}_{2} \cdot(5)$ Shuler et al.(6) have shown that $\mathrm{F}^{-}$or $\mathrm{SiF}_{6}=$ in nitric acid catalyzes the dissolution of $\mathrm{Th}$ or $\mathrm{ThO}_{2}$. In all mineral acids except hydrofluoric and sulfur1c, $\mathrm{Pa}^{233}$, the parent of $\mathrm{U}^{233}$, forms an unstable solution and eventually precipitates or becomes colloidal. (7) With hydrofluoric acid 1t forms the stable complex ion $\mathrm{PaF}_{7}=$.

Thorlum metal wafers that weigned 30 to $70 \mathrm{~g}$ were cut from the center of irradiated elements and were dissolved as follows: About $300 \mathrm{ml}$ of $15 \mathrm{M} \mathrm{HNO}_{3}-0.05 \mathrm{M} \mathrm{HF}$ were added to each wafer, and the mixture was heated at incipient boil for four hours. Another $100 \mathrm{ml}$ of $15 \mathrm{M} \mathrm{HNO}_{3}-0.05 \mathrm{M} \mathrm{HF}$ were then added; the metal was completely dissolved after about two more hours at inclplent boil. The solution was then diluted to one liter.

\section{SEPARATION OF URANIUM, THORIUM， AND Pa 233}

Thorium, protactinium, and uranium in the sample solution were separated by anion exchange by the method of Kraus, Moore, and Nelson. $(8, \theta)$ A $100-\mu l$ aliquot of the dissolved sample was dilutcd one thousandfold in $10 \mathrm{M} \mathrm{HCl}$, and one $\mathrm{ml}$ of the diluled sample was passed through a column of "Dowex" $1-\mathrm{X} 10,50-100$ mesh resin* (Figure 1) at 1.3 to $1.7 \mathrm{ml} /(\mathrm{min})\left(\mathrm{cm}^{2}\right)$. Thorium arld most of the fission products passed through the column because they do not form anionic complexes. The column was washed with two column volumes of $10 \mathrm{M} \mathrm{HCl}$, and the effluent and washes were collected f'or thorium analysis. Protactinium was eluted with three column volumes of $9 \mathrm{M} \mathrm{HCl}-0.5 \mathrm{M} \mathrm{HF}$. Uranium was eluted last with two column volumes

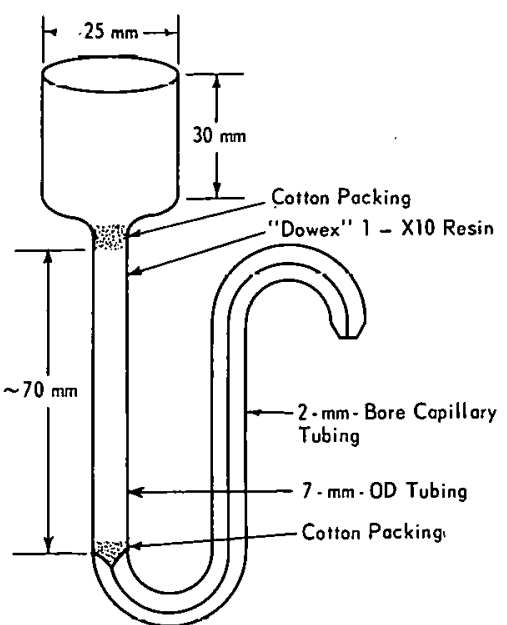

FIG. I ION EXCHANGE COLUMN of $0.1 \mathrm{M} \mathrm{HCl}$.

\footnotetext{
* "Dowex" is a trademark of Dow Chemical Co.
} 
The anion exchange separation was evaluated by analyzing a synthetic solution that contained known amounts of reagent-grade thorium nitrate, $\mathrm{U}^{235}, \mathrm{Zr}^{85}-\mathrm{Nb}^{95}$, and $\mathrm{Pa}^{233}$ (separated from $\mathrm{Np}^{237}$ by anion exchange) in $6 \mathrm{M}^{2} \mathrm{INO}_{3}$. An allquot of the synthet1c solution was diluted one thousandfold in $\mathrm{IOM} \mathrm{HCl}$, and one $\mathrm{ml}$ of the dilution was passed through the anion column. The separated thorium and protactinium were determined by the methods described in the next section; $U^{235}$ was determined by $2 \pi$ alpha counting. The recoveries are shown in Table I.

TABLE I

Recoveries from synthet1c solution.

\begin{tabular}{lr} 
Lonstituent & Recuvei.y $(a), \mathbb{f}$ \\
\hline Thorium & $98.3 \pm 1.0$ \\
$\mathrm{Pn}^{233}$ & $95.0 \pm 9.5$ \\
$\mathrm{U}^{235}$ & $98.2 \pm 2.6$
\end{tabular}

(a) Each analys 1 s was performed in triplicate. The precision is at the $95 \%$ confidence limit for a single delermination.

\section{DETERMINATION OF THORIUM AND $\mathrm{Pa}^{233}$}

The thorium fraction from the 1on exchange column was analyzed by the Thorin method. (10) The eluted $\mathrm{Pa}^{23} 3$ was counted by gamma spectrometry. Pa ${ }^{233}$ decays to $U^{233}$ with d half IIle of 27.0 days; therefore, the concentration of Facis must. be added to the determined concentration of $U^{233}$ to obtain the total $U^{233}$ produced. (See Appendix B for the spccific activity used.) The gamma detector was calibrated with $\mathrm{Pa}^{233}$ that had grown into secular equilibrium in an alpha-standardized $\mathrm{Np}^{237}$ solution.

\section{DETERMINATION OF URANIUM ISOTOPES BY MASS ANALYSIS AND ALPHA PULSE HEIGHT ANALYSIS}

Simple $2 \pi$ alpha counting could not be used for the determination of uranium isotopes. Instead APHA was necessary to determine the ratio of the alpha contributions from $\mathrm{U}^{232}$ and $U^{233}-U^{234}$ (combined peak). Mass analysis was used to calculate the contribution of the $\mathrm{U}^{234}$ to the $\mathrm{U}^{2.3 .3}-\mathrm{U}^{234}$ alpha peak. 
For mass spectrometric analyses, one to two milligrams of uranium were separated from each sample solution by anion exchange and were purified by ether extraction. After evaporation of the ether, the residue was oxidized to destroy organic material and was diluted to a known volume with water. Table II shows the mass analysis data obtained with a thermal emission mass spectrometer.

\section{$\underline{\text { TABLE II }}$}

Uranium Mass Analyses

\begin{tabular}{|c|c|c|}
\hline $\begin{array}{c}\text { Mass } \\
\text { No. }\end{array}$ & $\begin{array}{c}\text { Sample } A^{(a)} \text {, } \\
\text { wt } \%\end{array}$ & $\begin{array}{c}\text { Sample } \mathrm{B}^{(\mathrm{b})}, \\
\text { wt } \%\end{array}$ \\
\hline 232 & 0.016 & 0.020 \\
\hline 233 & 93.40 & 92.98 \\
\hline 234 & 4.21 & 5.14 \\
\hline 235 & 0.195 & 0.219 \\
\hline 236 & 0.007 & 0.009 \\
\hline 237 & (c) & (c) \\
\hline $238^{(d)}$ & 2.17 & 1.62 \\
\hline 239 & (c) & (c) \\
\hline
\end{tabular}

(a) An average of 18 scans. Calculated molecular we1ght: 233.6

(b) An average of 10 scans. Calculated molecular we1ght: 233.2

(c) Not detected.

(d) An 1mpurity normally present in thorium.

The value for mass 232 is not sufficlently precise or accurate as an independent method of measurement of $\mathrm{U}^{232}$ because: (1) traces of $\mathrm{Th}^{232}$ from the original sample could be present in the separated uranium, and (2) the tungsten filament of the mass spectrometer contalns some $T^{232}$ impurity. Even though the conditions used for mass analysis were believed to eliminate thorium emisolon, the mass 232 analysis still has an eotimated error of $\pm 15 \%$ at the concentration shown.

In preparation of samples for APHA, an aliquot of the uranium solution eluted from the anion column was electrodeposited on platinum from a hydrochloric acid medium. (11) This method was chosen as the best of three methods that were evaluated for preparing APHA sources. The other two methods were direct evaporation on stainless steel and evaporation on stainless steel of a hexone extraction of the separated uranium. Figure 2 shows a comparison of the data from plates 


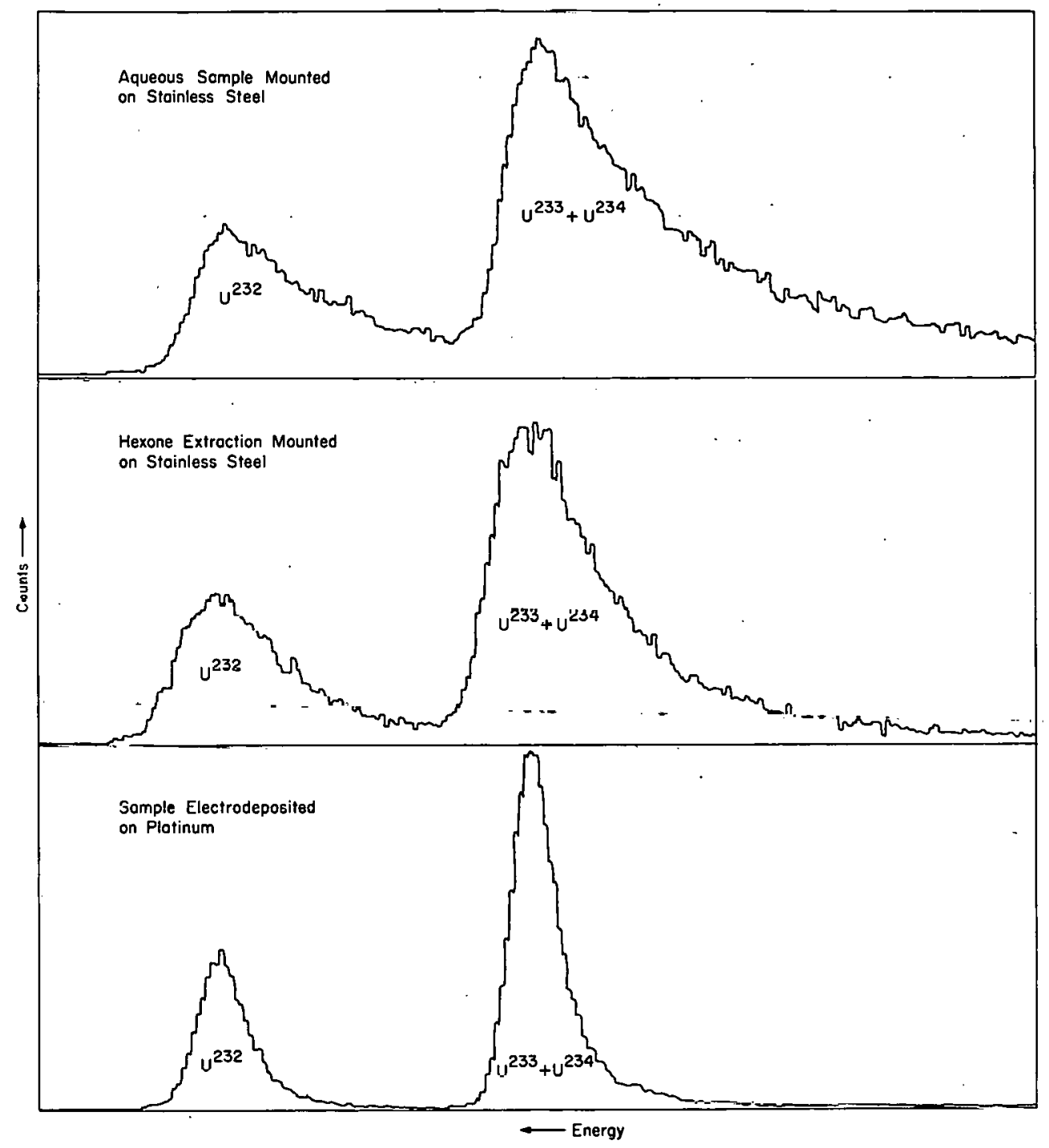

FIG. 2 ALPHA PULSE HEIGHT ANALYSES OF URANIUM ISOTOPES

prepared by the three methods. These data were produced with a Frisch grid chamber and multichannel analyzer. The electrodeposited mounts had a resolution of $1.5 \%$ vs. $23.5 \%$ for directly evaporated mounts. W1th the vetter resolution, the contribution of $\mathrm{U}^{232}$ to the $\mathrm{U}^{233}$ peak did not need to be calculated. l'able III shows the amount of $\mathrm{U}^{232}$ obtained by APHA analysis of electrodeposited samples.

The concentration of $\mathrm{U}^{234}$ must be known if APHA is used to determine $U^{232}$ in $U^{233}$ product. The data in the second column of Table III were calculated directly from APHA scans uncorrected for $\mathrm{U}^{234}$. The last column takes into account the correction for $\mathrm{U}^{234}$ as obtained by mass analysis. The higher the level of irradiation, the more significant the $U^{234}$

correction becomes. W1th or without the $U^{234}$ correction, the $\mathrm{U}^{232}$ concentrations exceeded the maximum limit of $170 \mathrm{ppm}$. 
Alpha Pulse Height Analyses of $U^{232}$ in $U^{233}$ Product (a)

Sample

A $\left(4.48 \mathrm{~kg} \mathrm{U} \mathrm{U}^{233} / \mathrm{ton} \mathrm{Th}\right)$

B $\left(5.75 \mathrm{~kg} \mathrm{U} \mathrm{U}^{233} / \mathrm{ton} \mathrm{Th}\right)$
Parts of $\mathrm{U}^{232}$ per Million Parts of $\mathrm{U}^{233}$

Analysis Uncorrected Analysis Corrected for $\mathrm{U}^{234}$ for $U^{234}$

188

$193 \pm 10$

235

$243 \pm 10$

(a) Each aralysis performed in quadruplicate. Precision is at the 95\% confidence limit for a single determination. All results were corrected for $\mathrm{Pa}^{233}$ decay. The specific activities used are in Appendix $B$.

\section{DETERMINATION OF U232 BY LOW GEOMETRY ALPHA COUNTING, MASS ANALYSIS, AND COULOMETRY}

As shown in Figure 3 , the determined $\mathrm{U}^{232}$ concentrations were higher than the $U^{232}$ concentrations reported $(2)$ for slightly different reactor loadings. Because of the importance of accurate analytical data on which to base plans for reactor loading in the production program, it was deemed advisable to verify the analytical results by an independent method. A combination of low geometry alpha counting (LGAC), mass analysis, and coulometry was devised to verify the results in Table III.

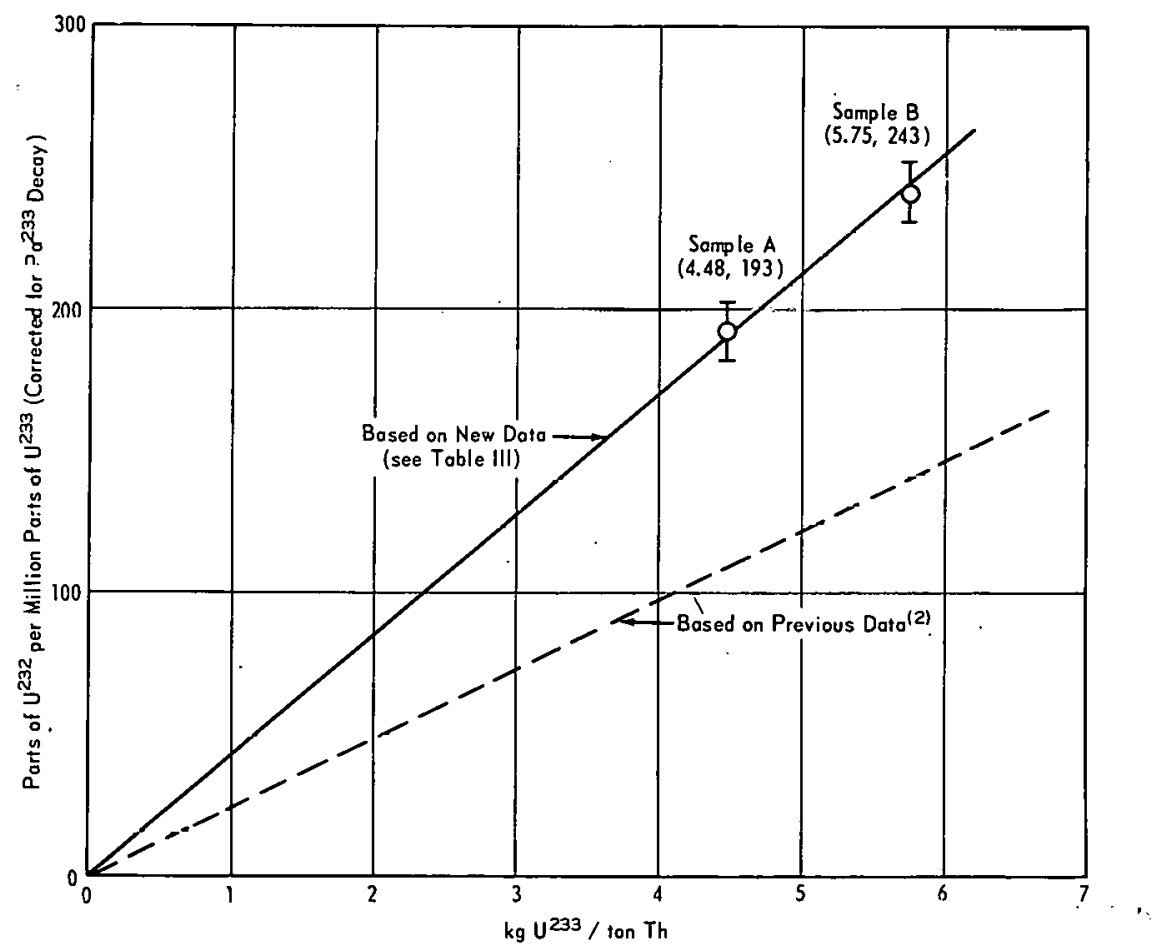

FIG. $3 U^{232}$ IN U U 233 PRODUCT VS PRODUCED U $U^{233}$ 
Portions of the purified samples prepared for mass analysis were taken for LGAC and coulometric analysis. Aliquots for IGAC were electrodeposited on platinum from a hydrochloric acid medium. (11) Uranium losses during electrodeposition averaged $3 \%$. To determine these losses, uranium was removed from the spent plating solution by ion exchange, then eluted and mounted for $2 \pi$ alpha counting.

The combined data from the IGAC and coulometric analyses are shown in Table IV.

\section{TABLE IV}

$\mathrm{U}^{232}$ in $\mathrm{U}^{233}$ Product by Coulometric-LGAC Method

\begin{tabular}{|c|c|c|c|}
\hline Sample & $\begin{array}{c}\text { Separated } \\
\text { II Cons by Coulometric } \\
\text { Method, } \mathrm{mg} / \mathrm{ml}(\mathrm{a})^{1} \\
\end{array}$ & $\begin{array}{l}\text { olution } \\
\text { Activity by LAAC, } \\
\quad \mathrm{d} /(\mathrm{ml} \mathrm{n})(\mathrm{ml})\end{array}$ & $\begin{array}{c}U^{232} \\
\ln U^{233} \text { Produot, } \\
\end{array}$ \\
\hline A & $0.204 \pm 0.003 \quad(n=3)$ & $5.76 \times 10^{6}$ & $166 \pm 24 \quad(n=10)$ \\
\hline$B$ & $0.523 \pm 0.009 \quad(n=3)$ & $1.67 \times 10^{7}$ & $249 \pm 17 \quad(n=4)$ \\
\hline
\end{tabular}

(a) Corrected for $\mathrm{Pa}^{233}$ decay.

(b) Precision at the $95 \%$ confidence limit for a single determination.

The $U^{232}$ in the $U^{233}$ product (last column of Table IV) was calculated from the following equation, whlch assumes that only $U^{232}, U^{233}$, and $U^{234}$ contribute to the counting rate:

$$
a e+b(1-e)=\frac{c}{d} \quad \text { or } \quad e=\frac{c-b a}{d(a-b)}
$$

where

$$
\begin{aligned}
& a=\text { the specific activity of } U^{232} \text { (from Appendix B), } \\
& \mathrm{d} /(\mathrm{sec})(\mathrm{mg}) \\
& \mathrm{b}=\text { the specific activity of } \mathrm{U}^{23.3}+\mathrm{U}^{2.34} \text { (calculated } \\
& \text { from Table II and data in Appendix } B), d /(\text { sec })(\mathrm{mg}) \\
& c=\text { uranium activity (from LGAC), } d /(\mathrm{sec})(\mathrm{mg}) \\
& d=\text { total concentration of } U^{232}, U^{233} \text {, and } U^{234} \\
& \text { (calculated from the coulometrically determined } \\
& \text { total uranium concentration on the basis of the } \\
& \text { isotopic concentrations in Table II), } \mathrm{mg} / \mathrm{ml} \\
& e=\frac{w t U^{232}}{w t\left(U^{232}+\cdot U^{233}+U^{234}\right)} \\
& I-e=\frac{w t\left(U^{233}+U^{234}\right)}{w t\left(U^{232}+U^{233}+U^{234}\right)}
\end{aligned}
$$


This evaluation of $e$ is based on the difference between two large, experimentally determined values (c - bd) and, therefore, is subject to a relatively large error. e is corrected for the $U^{234}$ concentration on the bas1s of Table II, and the $\mathrm{U}^{232}$ concentration is expressed as $\mathrm{ppm}$ of $\mathrm{U}^{233}$ (Table IV).

\section{CONCLUSIONS}

Differences between the two methods (Tables III and IV) are rather large w1th Sample $A$ but in good agreement with Sample B. The range of results on both samples overlap so. the methods are in agreement. As predicted, the range of error is smaller for the APHA method than for the coulometricLGAC method because the latter involves the difference between two large numbers. 


\section{APPENDIX A}

\section{FORMATION OF URANIUM ISOTOPES}

$\mathrm{U}^{233}$ is produced by thermal neutron irradiation of $\mathrm{Th}^{232}$ and subsequent decay as showr in Equation 1 .

$$
\operatorname{Th}^{232} \stackrel{(n, \gamma)}{\longrightarrow} \operatorname{Th}^{233} \frac{\beta}{22.4 \mathrm{~m}} \mathrm{~Pa}^{233} \frac{\beta}{27.0 \mathrm{~d}} \mathrm{U}^{233}
$$

Reactions that reduce the yield of $U^{233}$ are the neutron induced flision of $\mathrm{U}^{233}$ and $(n, \gamma)$ reactions on $\mathrm{Pa}^{233}$ and $\mathrm{U}^{233}$. Both of these $(n, \gamma)$ reactions produce $U^{234}$ as a final product.

Three fast neutron $(n, 2 n)$ reactions produce $U^{232}$, the most detrimental contaminant in $U^{233}$. Equation 2 shows how $>90 \%$ of the $U^{232}$ is formed.

$$
\begin{aligned}
& \operatorname{Th}^{232} \stackrel{(n, 2 n)}{\longrightarrow} \operatorname{Th}^{231} \frac{\beta}{25.6 \mathrm{~h}} \mathrm{~Pa}^{231} \stackrel{(\mathrm{n}, \gamma)}{\longrightarrow} \mathrm{Pa}^{232} \\
& \underset{1.31 d}{\stackrel{\beta}{d 32}}
\end{aligned}
$$

Minor amounts of $\mathrm{U}^{232}$ are produced by:

$$
\begin{aligned}
& \mathrm{U}^{233} \stackrel{(n, 2 n)}{\longrightarrow} \mathrm{U}^{232} \\
& \mathrm{~Pa}^{233} \stackrel{(n, 2 n)}{\longrightarrow} \mathrm{Pa}^{232} \frac{\beta}{1.31 \mathrm{~d}} \mathrm{U}^{232}
\end{aligned}
$$

The quantity of $\mathrm{U}^{232}$ produced is minimized if the uranium target slugs are placed in positions exposed only to thermal neutrons, thereby reducing the fast neutron ( $n$, $2 n$ ) reactions until large quantities of $U^{233}$ bulld up, fission, and supply appreciable quantities of fast neutrons.

Even small amounts of $\mathrm{U}^{232}(\sim 10 \mathrm{ppm})$ are undesirable because of the high gamma energy of 1 ts decay products (listed in the table on the following page). T1208 $(2.6 \mathrm{Mev})$, one of the highest energy gamma emitters known, emits $88 \%$ of the gamma activity above $1.2 \mathrm{Mev}^{(3)}$; the remaining $12 \%$ comes from $\mathrm{Bi}^{212}$. 


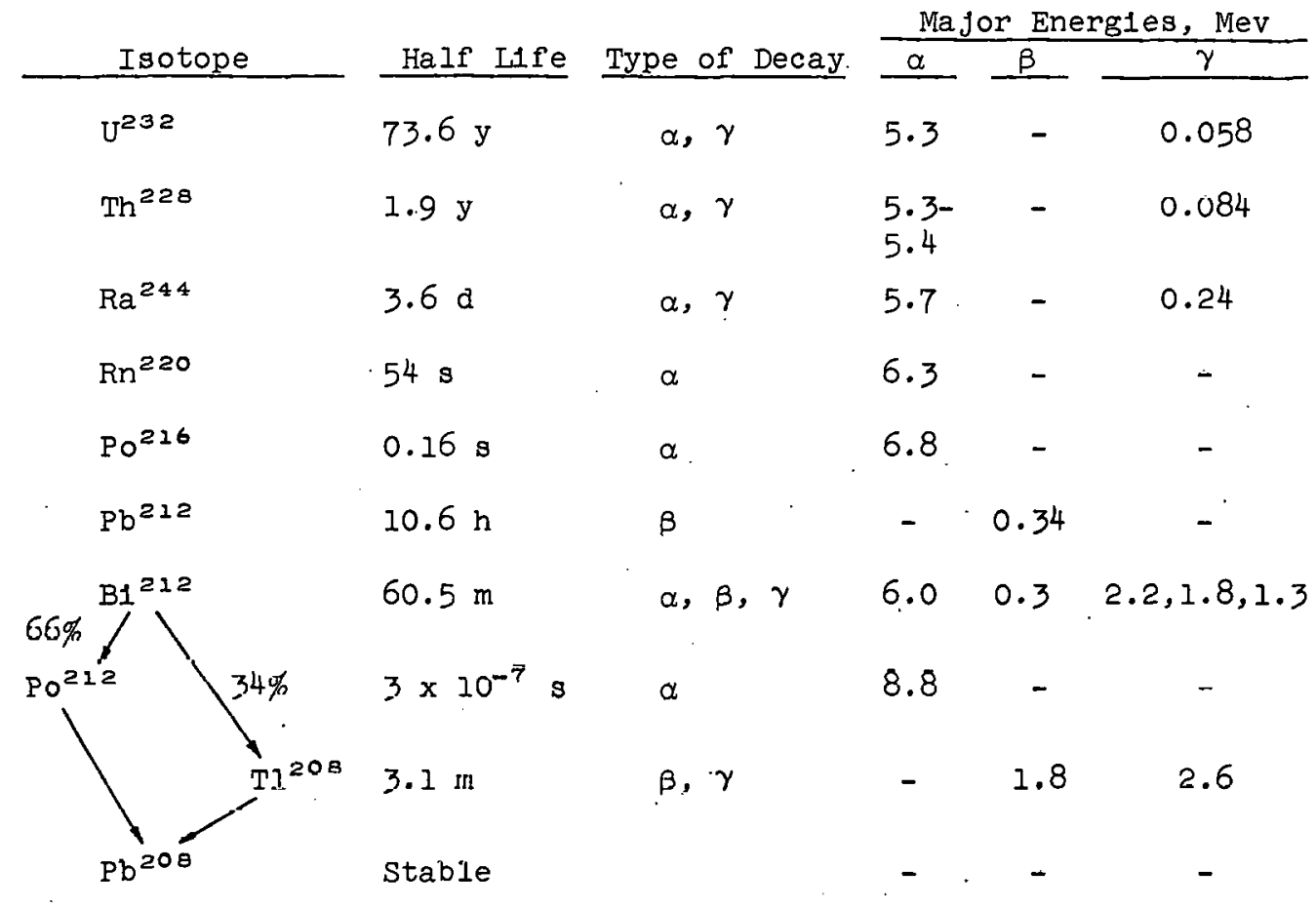

The activity of the decay chain reaches a maximum after 10 years and then follows the decay of 74 -year $U^{232}$. Knolls Atomic Power Laboratory reports that a uranium metal sphere with a $3.06-\mathrm{cm}$ radius ( $1 \mathrm{~kg}$ ) produced by irradiating thorlum to $4200 \mathrm{~g} /$ ton in the Materlals Testing Reactor would emit $690 \mathrm{r} / \mathrm{hr}$ at 1 ts surface after 10 years. (3) Los Alamos reports that $100 \mathrm{ppm}$ of $\mathrm{U}^{232}$ in a 3-cm-radius metal sphere of $\mathrm{U}^{233}$ would result in $1300 \mathrm{r} / \mathrm{hr}$ at the surface. In 10 years. (4) 
APPENDIX B

\section{HALF LIVES AND SPECIFIC ACTIVITIES}

There is a variation of several per cent in the uranium and protactinium half lives quoted by different authors. The values used in this report were:

$\begin{array}{lll}\text { Isotope } & \text { Half Life } & \begin{array}{c}\text { Speciflc Activity, } \\ \mathrm{d} /(\mathrm{sec})(\mathrm{mg})\end{array} \\ \mathrm{Pa}^{233} & 27.0 \mathrm{~d} & 7.70 \times 10^{11} \\ \mathrm{U}^{232} & 73.6 \mathrm{y} & 7.73 \times 10^{8} \\ \mathrm{U}^{233} & 1.62 \times 10^{5} \mathrm{y} & 3.52 \times 10^{5} \\ \mathrm{U}^{234} & 2.48 \times 10^{5} \mathrm{y} & 2.28 \times 10^{5}\end{array}$




\section{BIBLIOGRAPHY}

1. Sulla Fuel Reactors. J. R. Dletrich and W. H. Zinn, ed. Reading, Mass: Add1son-Wesley, p. 29 (1958).

2. Towler, O. A., Jr. "Thorlum Irradiation in $\mathrm{D}_{2} \mathrm{O}$-Moderated Reactors". Presented at Thorium Fuel Cycle Symposium, Gatilnburg, Tenn. (1962).

3. Feber, R. C. Implications of the U-232 Decay Chain Activity for the Processing of Irradiated Thorlum and Recovered U-233. KnolIs Atomlc Power Laboratory, Schenectady, N. Y. USAEC Report KAPL-1271, 32 pp. (February 1955) (declassified Apri1 3, 1957).

4. Devaney, J. J. Radiation Intensity from Spheres of $U^{233}$ Contaminated w1th $\mathrm{U}^{232}$. Los Alamos Scientific Laboratory, New Mexico. USAEC Report LAMS-1892, 5 pp. (February 1955).

5. Katzin, L. I. "Recent Developments in the Chemistry of Thorium". Proc. U. N. Intern. Conf. Peaceful Uses Atomic Energy, 1st, Geneva, I, 407-13 (1955).

6. Schuzer, F. W., F. L. Steahly, and R. W. Stoughton. Dissolution of Thorlum Metal and Thorlum Dioxide in $\mathrm{HNO}_{3}-\mathrm{HF}$ and $\mathrm{HNO}_{3}-\left(\mathrm{NH}_{4}\right)_{2} \mathrm{~S}_{6}$ M1xtures. Paper 7.1 of Production and Separation of $U^{233}$. USAEC Technical Information Service Extension, Oak Ridge, Tenn. National Nuclear Energy Ser1es NNES-IV-17B, Pt. 1, pp. 307-317 (1952).

7. Kirby, H. W. The Radiochemistry of Protactinium. Monsanto Chemica.1. Co., Mound Laboratory, Miamisburg, Oh1o. USAEC Report NAS-NS-3016, $85 \mathrm{pp}$. (December 1959).

8. Kraus, K. A., G. E. Moore, and F. Nelson. "Anion-Exchange Studies. XXI. Th(IV) and U(IV) in Hydrochloric Acid. Separation of Thorium, Protactinium and Uranium". J.Amer. Chem. Soc. 78 , 2692-94 (1956).

9. Kraus, K. A. ard F. Nelson. "Anion Exchange Studies of the Fission Products". Proc. U. N. Intern. Conf. Peaceful Uses Atomic Energy, 1st, Geneva, I, 113-25 (1955).

10. Thomason, P. F., M. A. Perry, and W. M. Byerly. "Determination of Microgram Amounts of Thor1um". Anal. Chem. 21, 1239-41 (1949).

11. Mitchell, R. F. "Electrodeposition of Actinide Elements at Tracer Concentrations". Anal. Chem. 32, 326-8 (1960). 